Portland State University

PDXScholar

Winter 2008

\title{
Along the Oregon Trail: Disaster Preparedness in Oregon Libraries and Archives
}

Kristen Kern

Portland State University, kernk@pdx.edu

Follow this and additional works at: https://pdxscholar.library.pdx.edu/ulib_fac

Part of the Library and Information Science Commons

Let us know how access to this document benefits you.

\section{Citation Details}

Kern, Kris. "Along the Oregon Trail: Disaster Preparedness in Oregon Libraries and Archives." OLA Quarterly. Vol 14, no. 4 (Winter 2008): 17-19.

This Article is brought to you for free and open access. It has been accepted for inclusion in Library Faculty Publications and Presentations by an authorized administrator of PDXScholar. Please contact us if we can make this document more accessible: pdxscholar@pdx.edu. 


\section{Along the Oregon Trail: Disaster Preparedness in Oregon Libraries and Archives}

\section{by Kristen Kern} WESTPAS Trainer and Preservation Librarian, Portland State University
$\mathrm{O}$ regon is endowed with unique historic collections that are held in public and academic libraries and local archives across our state. These books, documents, and artifacts capture the history and collective memories of a place and its people, contributing a deep sense of community.

Protecting these collections is a critical responsibility for staff that already have too much to do, whether paid or volunteer. At the same time, our libraries and archives are challenged by large distances between population centers. When faced with volcanos, earthquakes, tsunamis, floods, fires, mold and pest infestations, help is too far away; institutions often must rely on their own resources to address them. Disaster preparedness is vital to ensure an effective response to the hazards that can befall us.

Surveys undertaken at the state and national levels have shown the need for disaster preparedness training. In 1995, an OLA survey conducted by the Special Committee on Preservation revealed that only 13 percent of the over 100 libraries responding possessed a disaster plan. The Committee determined then that disaster planning was an achievable goal that met the training need respondent libraries repeatedly requested. Since that survey was conducted, several workshops have been presented on disaster preparedness and other preservation topics, primarily in the Willamette Valley.

A significant national preservation survey, the Heritage Health Index (HHI), was carried out in 2005 by Heritage Preservation, a non-profit organization devoted to advocating for the preservation of the nation's cultural heritage. It was the first comprehensive survey to assess the condition and preservation needs of cultural collections in the United States. Four key recommendations resulted from the survey, including one stating that every collecting institution must develop an emergency plan to protect its collections and train staff to carry it out. Among the findings, $\mathrm{HHI}$ discovered that in the Western and Pacific region, 90 percent of the institutions responding to the survey were of medium or small size and fewer than 20 percent included paid preservation staff. Staff education and training was listed as a primary need for 70 percent of the institutions. Directly related to disaster preparedness, it was found that fewer than 20 percent of smaller institutions have current disaster response and salvage plans with staff trained to carry them out. Both the 1995 survey of Oregon libraries and the HHI findings for the Western United States indicate that an overwhelming majority of library and archives, particularly modestly sized ones, lack this basic tool, a disaster plan, for protecting their collections and staff trained to implement it.

Clearly it is important to ensure that a greater number of libraries and archives in our state and region are prepared to respond to a disaster involving their collections. While many other states are currently served by regional preservation field services that offer education, training, and disaster response assistance for libraries and archives, Oregon is not among them. To provide comparable services in the Western and Pacific region that are organized to overcome the challenges of great geographic distances between population centers, the Western States and Territories Preservation Assistance Service (WESTPAS) was created in 2007. The cost of the WESTPAS project's initial planning phase was underwritten by Preservation Technologies, LP. WESTPAS is funded primarily by a grant from the National Endowment for the Humanities (NEH). Additional funding has been provided by Belfor, an

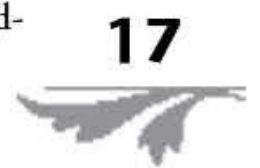




\section{The Heritage Health Index found that:}

- 80 percent of collecting institutions do not have an emergency plan that includes collections, with staff trained to carry it out.

- 71 percent of institutions need additional training and expertise for staff caring for their collections.

- 12.6 million black and white photographic prints are in urgent need of treatment or attention by a skilled, professional conservator if they are to remain available for exhibition or research.

- 2.6 billion items of historical, cultural and scientific significance are not protected by an emergency plan and are at risk should a disaster strike their institutions.

For further information on the results of the Heritage Health Index, visit: http://www.heritagepreservation.org/ $\mathrm{HHI} /$

\section{8}

international disaster recovery service, and Archival Products, producer of preservation binders and enclosures. In the last two years, WESTPAS has become the major preservation information, education, and training service for libraries and archives in 11 states: Hawai'i, California, Washington, Alaska, Idaho, Nevada, Wyoming, Utah, Montana, Colorado, and Oregon, and three territories: Guam, Northern Marianas and American Samoa.

The foundation of WESTPAS has been influenced by several organizations and initiatives based in the region, including the Balboa Art Conservation Center (BACC) which has an NEH funded preservation field service program dedicated primarily to museums in Arizona, California, Oregon and Washington; the Washington Preservation Initiative which provided numerous preservation workshops in 2003-2006; the Seattle-based Pacific Northwest Preservation Management Institute in 2004-05; and the Portland Area Library System (PORTALS) Disaster Recovery Group offering disaster preparedness trainings and information since 2000. It is the California Preservation Program (CPP), though, that provided the chief factors contributing to the success of WESTPAS by utilizing its organizational model, training models, expertise and experience. WESTPAS Program Coordinator Barclay Ogden, Preservation Librarian at the University of California, Berkeley, and Julie Page, User Services Coordinator, national consultant and retired Preservation Librarian at University of California, San Diego, have served for a number of years as co-chairs of the CPP.

WESTPAS is organizationally a project of the Peninsula Library System (PLS), a consortium of public and community college libraries. PLS serves as WESTPAS's fiscal administrator, provides scheduling and registration assistance and prepares workshop training materials.

The WESTPAS project has focused its efforts in 2007 and 2008 on disaster preparedness training and the creation of disaster response plans for 600 staff members representing 400 libraries and archives in the designated states and territories. Significantly, the NEH funding permits the content and supplies of disaster preparedness workshops to be offered at no cost to attendees as well as covering travel expenses for trainers. As of this writing, the results thus far have greatly exceeded expectations: the number of participants in workshops is double original projections and most participating institutions have completed disaster preparedness plans. In addition to training, WESTPAS established a Web site that provides information concerning workshops, maintained a 24/7 telephone answering service for collection emergencies, and developed an e-mail/ phone consulting service.

Each disaster planning workshop is scheduled in coordination with the trainer, the state liaison and the local site, usually a library or archive. Val Vogt and, after Val's retirement, MaryKay Dahlgreen were very helpful in searching out and securing library meeting room space for the workshops. The workshops include two sessions normally scheduled four to eight weeks apart. After registering, confirmed participants are given "homework" assignments. First they are asked to acquire a letter from their administration supporting their attendance to bring to the first session. One of the chief predictors of successful planning is administrative support for a process that takes up staff time and financial resources. Registrants are also sent a disaster plan template customized for the state. This two sided plan is based on the popular Council of State Archivists PReP-Pocket Response Plan-and pro- 
vides a starting point for gathering pertinent information required to complete the plan. Participants are asked to consider their collection priorities and bring the contact information for any local experts, supplies or services commercially available that they know of or would recommend.

The first workshop session emphasizes the importance of preparedness, communication, knowledge of institutional priorities, and insurance coverage. A list of carefully selected Web sites and print resources on disaster planning are available for workshop attendees.

During the intervening weeks between the first and second workshop sessions, participants are expected to complete as much as possible of the plan: contact information for all critical administrative personnel, facilities personnel, the disaster response team, first responders (fire, police) and salvage priorities. In addition, attendees are charged with the task of assigning responsibilities and roles to staff responding to an emergency, such as who will make sure that damage has been documented in photos or video? Additional "homework" assignments are to gather information about the building's facilities: do you know where the main shut off valve for your water supply is? and to research the institution's insurance policy, answering questions such as what kind of insurance do you have? Will you be able to replace damaged materials?

The second session covers issues related to recovery and training. Working with a disaster recovery service is discussed. Every emergency is unique and staff alone can resolve many of them successfully. When an event is beyond the capacity of the library or archive's own personnel, a disaster recovery company's services may be necessary to salvage collections. A critical component of recovery, the accurate inventorying and tracking of affected collections, is addressed. Ways to involve and prepare staff to respond effectively to emergencies are presented. A hands-on exercise salvaging wet library and archive materials breaks up the afternoon presentation.

Three WESTPAS disaster planning workshops have been presented in Oregon. The La Grande Public Library hosted the state's inaugural workshop in the fall of 2007. In the summer of 2008, the Eugene Public Library provided a home for the workshop and the final Oregon presentation took place at the Beaverton City Library. The willingness of these libraries to cheerfully share their community rooms, provide refreshments for participants, bravely offer up weeded books and media for water damage, and ensure technology functioned has been humbling and gratifying. To Jo Cowling, Connie Bennett and Maureen Cole and Ed House- it wouldn't have been possible without you and your staff. Thank you!

\section{References}

Helmer, N. (1997). The State of Oregon Preservation in 1995. OLA Quarterly 3(2), 2-5, 17.

Ogden, B. (2008) Final draft of WESTPAS grant application to NEH.

Page, Julie, with Lynn Ann Davis, Kristen

Kern, Gary Menges, Barclay Ogden, and Randy Silverman. Western States \& Territories Preservation Assistance Service Workshop presentation material for Protecting Library \& Archive Collections: Disaster Preparedness, Response and Recovery. 2007. 